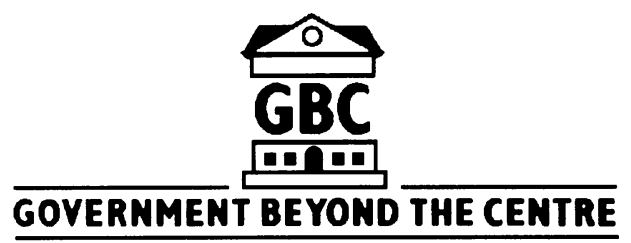

SERIES EDITOR: GERRY STOKER

The world of sub-central government and administration including local authorities, quasi-governmental bodies and the agencies of public-private partnerships - has seen massive changes in recent years and is at the heart of the current restructuring of government in the United Kingdom and other Western democracies.

The intention of the Government Beyond the Centre series is to bring the study of this often-neglected world into the mainstream of social science research, applying the spotlight of critical analysis to what has traditionally been the preserve of institutional public administration approaches.

Its focus is on the agenda of change currently being faced by subcentral government, the economic, political and ideological forces that underlie it, and the structures of power and influence that are emerging. Its objective is to provide up-to-date and informative accounts of the new forms of government, management and administration that are emerging.

The series will be of interest to students and practitioners of politics, public and social administration, and all those interested in the reshaping of the governmental institutions which have a daily and major impact on our lives. 


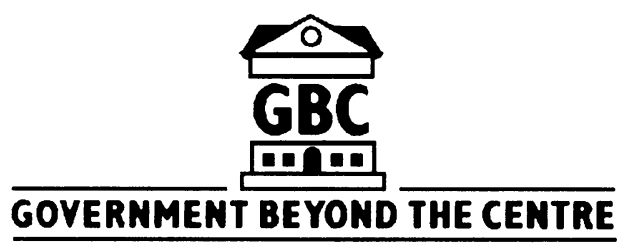

SERIES EDITOR: GERRY STOKER

Published

Wendy Ball and John Solomos (eds)

Race and Local Politics

Richard Batley and Gerry Stoker (eds)

Local Government in Europe

Clive Gray

Government Beyond the Centre

John Gyford

Citizens, Consumers and Councils

Richard Kerley

Managing in Local Government

Steve Leach, John Stewart and Kieron Walsh

The Changing Organisation and Management of Local Government

Yvonne Rydin

The British Planning System

John Stewart and Gerry Stoker (eds)

Local Government in the 1990s

David Wilson and Chris Game (with Steve Leach and Gerry Stoker)

Local Government in the United Kingdom

\section{Series Standing Order}

If you would like to receive future titles in this series as they are published, you can make use of our standing order facility. To place a standing order please contact your bookseller or, in case of difficulty, write to us at the address below with your name and address and the name of the series. Please state with which title you wish to begin your standing order. (If you live outside the UK we may not have the rights for your area, in which case we will forward your order to the publisher concerned.)

Standing Order Service, Macmillan Distribution Ltd, Houndmills, Basingstoke, Hampshire, RG21 2XS, England 


\title{
Local Government in the 1990s
}

\author{
Edited by \\ John Stewart \\ and \\ Gerry Stoker
}

MACMILLAN 
Selection, editorial matter and Chapters 1 and 11 (C) John Stewart and Gerry Stoker 1995

Individual chapters (in order) (C) Tony Travers, Kieron Walsh, Steve Leach, John Stewart, David Prior, Stewart Ranson, Martin Willis, Kenneth M. Spencer, Alan Harding and Peter Garside, Gerry Stoker and Karen Mossberger, Desmond King, John Stewart 1995

All rights reserved. No reproduction, copy or transmission of this publication may be made without written permission.

No paragraph of this publication may be reproduced, copied or transmitted save with written permission or in accordance with the provisions of the Copyright, Designs and Patents Act 1988, or under the terms of any licence permitting limited copying issued by the Copyright Licensing Agency, 90 Tottenham Court Road, London W1P 9HE.

Any person who does any unauthorised act in relation to this publication may be liable to criminal prosecution and civil claims for damages.

This book replaces The Future of Local Government (1989, reprinted 1991, 1992)

First published 1995 by

THE MACMILLAN PRESS LTD

Houndmills, Basingstoke, Hampshire RG21 2XS

and London

Companies and representatives

throughout the world

ISBN 978-0-333-61684-0

ISBN 978-1-349-23815-6 (eBook)

DOI 10.1007/978-1-349-23815-6

A catalogue record for this book is available from the British Library.

Copy-edited and typeset by Povey-Edmondson

Okehampton and Rochdale, England 


\section{Contents}

List of Tables vii

Notes on the Contributors viii

Preface xi

1 Introduction 1

John Stewart and Gerry Stoker

I STRUCTURE, FINANCE AND MANAGEMENT

2 Finance 9

Tony Travers

3 Competition and Public Service Delivery 28 Kieron Walsh

4 The Strange Case of the Local Government Review 49 Steve Leach

5 The Internal Management of Local Authorities $\quad 69$ John Stewart

6 Citizen's Charters $\quad 86$ David Prior

\section{SERVICES AND FUNCTIONS}

7 From Reforming to Restructuring of Education 107 Stewart Ranson

8 Community Care and Social Services 126 Martin Willis

9 The Reform of Social Housing Kenneth M. Spencer

10 Urban and Economic Development Alan Harding and Peter Garside 


\section{WHAT PAST? WHAT FUTURE?}

11 Fifteen Years of Local Government Restructuring 1979-1994: An Evaluation John Stewart and Gerry Stoker

12 The Post-Fordist Local State: The Dynamics of its Development

Gerry Stoker and Karen Mossberger

13 From the Urban Left to the New Right: Normative Theory and Local Government

Desmond King

14 A Future for Local Authorities as Community Government

John Stewart

Index 


\section{List of Tables}

2.1 Largest redistribution of resources between authorities 16

2.2 Impact of move from rates to community charge 17

8.1 Gross revenue expenditure by local authorities $\quad 126$

10.1 DoE urban expenditure 171

12.1 New wave management: the 4 ' $S$ ' model 218

13.1 Five theories of local government 243

14.1 Average population size of local authorities 253 


\section{Notes on the Contributors}

Peter Garside is a research associate at the European Institute of Urban Affairs, Liverpool John Moores University. He was a member of the research team that recently completed an assessment of the impact of natural urban policies for the Department of the Environment and he has particular expertise on the role of advanced service industries in urban regeneration. He is currently involved in evaluation of the City Challenge at the national level and at Hulme, Manchester.

Alan Harding is a Senior Research Fellow at the European Institute of Urban Affairs, Liverpool John Moores University. He has published widely on urban development and urban policy issues within the UK and in Europe and is currently conducting a crossnational research project on the politics of urban change as part of the Economic and Social Research Council's Local Government Initiative. $\mathrm{He}$ is co-author of Urbanisation and the Functions of Cities in the European Community (1993) and co-editor of European Cities in the 1990s: Profiles, Policies and Prospects (1994).

Desmond King is a Fellow of St John's College, Oxford. His publications include The New Right: Politics, Markets and Citizenship (1987) and (co-editor) Challenges to Local Government (1990).

Steve Leach is a Senior Lecturer at INLOGOV, University of Birmingham. He has written widely on local politics, policy planning and most recently, local government reorganisation. One of his most recent publications, written with John Stewart, is The Politics of Hung Authorities.

Karen Mossberger is a PhD candidate at the Department of Political Science, Wayne State University, Detroit, USA. During 1992-3 she was a research assistant to Gerry Stoker, funded by Strathclyde University. 
David Prior is Head of Policy Development in the Strategic Management Department of Birmingham City Council. He also manages the Public Policy Partnership, a joint venture between Birmingham City Council and the School of Public Policy at the University of Birmingham. He has written on various aspects of local government management and is currently co-authoring a book on citizenship and its significance for local authorities.

Stewart Ranson is Professor of Education in the School of Education at the University of Birmingham. He has written widely on the changing government and politics of education and is leading the major education management study with the ESRC Local Governance Programme.

Kenneth M. Spencer is Professor of Local Policy, Head of the Department of Local Government Studies and Director of INLOGOV at the University of Birmingham. He has written books and articles on housing policy and management, the voluntary sector and on regional economic development. He is a member of the European Union's Committee of Experts advising the Regional Policy Directorate.

John Stewart is Professor of Local Government and Administration at the Institute of Local Government Studies (INLOGOV), University of Birmingham. His previous books include The Future of Local Government (with Gerry Stoker).

Gerry Stoker is Professor of Politics, University of Strathclyde, and Co-ordinator of the five-year ESRC Local Governance Research Programme. His previous books include The Politics of Local Government and Remaking Planning (with Tim Brindley and Yvonne Rydin).

Tony Travers is Director of Research, Greater London Group, London School of Economics and Political Science. He has published widely both in book and journal form.

Kieron Walsh is Professor of Local Government Management, Institute of Local Government Studies, University of Birmingham. He has worked extensively on issues of contracting and competition 
and the public service. He has recently published Competition and Service: The Implications of the Local Government Act 1988. He is presently completing a study of the use of market mechanisms in public service management. He is author of a number of books and articles on management in the public service.

Martin Willis is the Director of the Social Services Management Unit (SSMU), in the Department of Social Work and Social Policy at the University of Birmingham. SSMU is a self-financed provider of training, consultancy and research to local government, voluntary and private organisations. His past experience encompasses social work, management and economics. A recent publication is Older People and Equal Citizenship (1992). 


\section{Preface}

When we edited The Future of Local Government, which was published in 1989, we felt then that the pace of change facing local government was considerable. Nothing has happened over the last five years to change our minds! Indeed because local government has experienced so much change we thought it appropriate to produce a second edited text to provide an up-to-date picture of the emerging system. The chapters in this new book are provided by many of the authors from The Future of Local Government along with several new faces. All of the writers have operated to very tight deadlines and in the context of shifting targets in relation to changing policy and practice. The book is as up-to-date as it can be but we hope that readers will bear in mind that most of the authors completed their writing in January 1994. Overall, our aim has been to place the extraordinary set of changes within local government in context and provide some insight into likely future directions.

We would like to thank all of those who helped to produce the book. Steven Kennedy at the publishers was as helpful as ever. Kathy Bonehill at Birmingham and Fiona Thorpe at Strathclyde helped greatly to smooth the production of the book. Thanks also to Teresa, Deborah, Bethany, Robert and Benjamin.

John Stewart Gerry Stoker 